\title{
Epidemiological study of human intestinal parasites in Sarawak, East Malaysia: A review
}

\author{
Tahar, A.S. ${ }^{1}$, Bilung, L.M. ${ }^{1 *}$, Apun, K. ${ }^{1}$, Richard, R.L. ${ }^{2}$, Lim, Y.A.L. ${ }^{*}$ \\ ${ }^{1}$ Faculty of Resource Science and Technology, Universiti Malaysia Sarawak, 94300 Kota Samarahan, Sarawak, Malaysia \\ 2Department of Science and Technology Studies, Faculty of Science, University of Malaya, 50603, Kuala Lumpur, Malaysia \\ ${ }^{3}$ Department of Parasitology, Faculty of Medicine, Universiti Malaya, 50603 Kuala Lumpur, Malaysia \\ *Corresponding authors: mblesley@unimas.my, limailian@um.edu.my
}

\section{ARTICLE HISTORY}

Received: 15 April 2021

Revised: 4 August 2021

Accepted: 5 August 2021

Published: 30 August 2021

\begin{abstract}
Intestinal parasitic infections are endemic in rural settings and may account for asymptomatic infections to various health complications. These infections are a cause of concern for communities of lower economic status, especially in developing countries. In Sarawak, indigenous populations residing in geographically inaccessible areas are socially and economically disadvantaged. Through close association with nature, these populations are prone to intestinal parasitism. Currently, scattered information has led to a continual state of neglect at each level of parasitic infection control. This urges for a review of their distribution and transmission based on previous reports to understand the pattern of the diseases in the state which can further address the improvement of mass controlling programs. A literature search was conducted to collect previous reports on human intestinal parasites in Sarawak, East Malaysia from PubMed (Medline), SCOPUS, ScienceDirect and Web of Science from January 2019 to March 2021. Extrapolating the current data in Sarawak which is still considered limited, further interdisciplinary strategies are demanded to give insights in the epidemiology and true prevalence of intestinal parasites in Sarawak. This review addresses for redirection of attitude towards intestinal parasitic infections where it should be given with ample attention by rural populations. In tandem to that, improvement of rural livelihood such as standard of living and sanitation in Sarawak should be accredited as part of the efforts to reduce the number of intestinal parasitic infections in the state. As a control measure, mass deworming should be reconsidered especially to the rural populations.
\end{abstract}

Keywords: Intestinal parasites; nematode; protozoa; indigenous populations; Sarawak.

\section{INTRODUCTION}

Sarawak is the largest state in Malaysia which is nearly as large as the Peninsular Malaysia. It is situated in the northwest Borneo region and has a complex ethnic and cultural backgrounds (i.e. races and indigenous groups) that comprise approximately 2.656 million population in 2020 (DOSM, 2021). Iban is the largest proportion of this diversity, in addition to the composition of other races which include Malay, Chinese, India and indigenous populations comprising Baketan, Betawan, Bisaya, Kayan, Kedayan, Kejaman, Kelabit, Kenyah, Lahanan, Lisum, Longkiput, Lun Bawang, Melanau, Penan, Sekapan, Sihan, Tagal, Tabun and Ukit (Ting \& Ling, 2013). Each of these ethnic groups has different language, culture and lifestyles. The sociodemographic backgrounds for these communities usually involve living in longhouses, practising self-subsistence (e.g. cultivation, animal husbandry and fishing) and located remote to urban and semi-urban areas. However, for the
Penan tribes, they were used to be unsettled, huntergatherers and dependable on food from deep jungles (e.g. wild sago, wild plants and wild animals). Penan tribes were also regarded as the most marginalised and disadvantaged due to their nomadic lifestyle before transitioning to being partial or fully settled (Sercombe, 2020).

Sarawak has 93 water treatment plants that produced 1,328 million litres per day (MLD) of water production (National Water Services Commission, 2018a) and 474 MLD of domestic consumption in 2016 (National Water Services Commission, 2018b). Provision of drinking water in Sarawak, in terms of area of supply and distribution, can be divided into two clusters which are urban and rural water supplies. Urban areas in Sarawak are provided by the state-governed water bodies which are Kuching Water Board (KWB) in Kuching, Sibu Water Board in Sibu and Northern Region Water Board (LAKU) in Northern Regions of Sarawak, whilst, most rural regions are reliant on the water supplied by Sarawak Rural Water Supply Department (JBALB). As there are limited 
remote areas having access to potable water and provision of water supply is not given by the above government bodies, gravity-feed system, rainwater-harvesting system, rivers and groundwater (faucet) are the sole attainable alternatives.

Several infectious diseases are endemic in Sarawak such as malaria (Cheong et al., 2013), leptospirosis (Thayaparan et al., 2013), cholera (Patrick et al., 2012), melioidosis (Mohan et al., 2017), hand, foot, and mouth disease (HFMD) (Sham et al., 2014), Japanese encephalitis (JE) (Impoinvil et al., 2013) and rabies (Muthu, 2018). Unlike these diseases, intestinal parasitic infections (IPIs) do not receive a proper concern owing to its subclinical symptoms and neglected status. In order to meet the provision of health services that can be served to all populations in the state, many hospitals, community clinics, mobile teams, flying doctor services (i.e. exclusively in remote areas) have been in existence across Sarawak.

Given the scattered information on intestinal parasites in Sarawak, this review is intended to collate previous information pertaining to human intestinal parasites in humans and environments (i.e. water, animals and food samples) with a special focus in Sarawak as the state in Malaysia with most rural communities. The content also describes the distributions and transmission potentials of the parasites in the state. This article addresses how intestinal parasitism is acquired and its burden in Sarawak populations.

\section{MATERIALS AND METHODS}

As a strategy to collect information that addressed the prevalence of human intestinal parasites in Sarawak, East Malaysia, a database search from PubMed, Medline, Science Direct and Web of Science was conducted utilising keywords 'parasites', 'intestinal parasites', 'protozoa', 'helminth', 'Cryptosporidium', 'Giardia', 'Ascaris', 'hookworm', 'Trichuris', 'zoonotic parasites', 'waterborne parasites' and 'foodborne parasites' in combination with the keyword "Sarawak" from January 2019 to March 2021. Criteria for articles selected for this review are: i) reporting parasites of humans (i.e. parasites infecting only animals and plants were excluded), ii) involving intestinal parasites and not blood parasites (e.g. Plasmodium sp., Brugia sp.) or ectoparasites, iii) clinical cases and prevalence studies are included into selection, iv) reported in the state of Sarawak in East Malaysia, v) reports were published prior March 2021, vi) reports with full text and are available in English. All searched articles were fully read. If the mentioned criteria were not fulfilled, the articles were excluded from being selected in this review.

\section{RESULTS}

\section{Intestinal parasitism in humans}

\section{Prevalence of intestinal parasitism}

A recent database search showed a total of 12 published reports have been available from 1967-2020 on the incidences of intestinal parasitic infections (IPIs) in human samples caused by protozoan parasites and helminths in Sarawak. Most prevalent infections have been discretely recorded on soil-transmitted helminths (i.e. Ascaris lumbricoides, hookworm and Trichuris trichiura) among other intestinal parasites. According to these reports as summarised in Table $1, T$. trichiura is the most frequently encountered and has impacted at least 256 of 1395 individuals (18.4\%), followed by hookworm $(174 / 1395,12.5 \%)$ and $A$. lumbricoides (130/1395, $9.3 \%)$. Apart from that, other intestinal parasites include
Cryptosporidium spp. (1/381, 0.26\%), Giardia lamblia (16/643, 2.5\%), Strongyloides stercoralis $(26 / 236,11 \% *)$, Toxoplasma gondii (106/212, 50\%*) Sarcocystis spp. (1/1, 100\%), Schistosoma spp. (25/367, 6.8\%), Entamoeba spp. (25/501, 5.0\%), Enterobius vermicularis (13/262, 5.0\%), lodamoeba butschlii (2/142, 1.4\%) and Chilomastix mesnili (2/142, 1.4\%).

Recorded reports remain patchy to some small areas, which include 6 out of 12 divisions comprising Kuching, Serian, Betong, Sarikei, Kapit and Miri as displayed in Figure 1. Human infection cases have involved rural indigenous populations and hospital patients. The indigenous tribes involved are Iban, Kayan, Kenyah, Kajang, Ukit, Penan and Lahanan. There are two studies with no race information is available which are the studies by Othman et al. (2015) and Basuni et al. (2011). Thus, the data are only grouped as "hospital patients" for the population type (Table 1). There are two case reports found comprising a case report on sarcocystosis in a Chinese cancer patient from Kapit (Pathmanathan \& Kan, 1987), and a case report on ascariasis in an Indonesian presented to a district hospital in Kuching (Stephen \& Siow, 2012). The study by Othman et al. (2015) reported that 94 hospital patients with malarial symptoms were infected with $A$. lumbricoides $(6 / 94,6.4 \%)$, S. stercoralis (29/94, 30.9\%) and hookworm (28/94, 29.8\%). Based on previous studies, chronic helminth infection can modulate host immunity in a way that co-infections in malarial infected individuals may ameliorate or worsen the severity (Hartgers \& Yazdanbakhsh, 2006). Almost similar prevalence was also presented by Basuni et al. (2011) where hospital patients with abdominal symptoms were infected with $A$. lumbricoides $(6 / 77,7.8 \%)$, S. stercoralis $(30 / 77,39.0 \%)$ and hookworm (31/77, 40.1\%).

As shown in Table 1, A. lumbricoides and hookworm are the most prevalent among Iban communities in Pakan Town (Rajoo et al., 2017), however hookworm and T. trichiura are prevalent in Seratok (Neo et al., 1987). Conversely, T. trichiura is significantly the highest among other parasites in Kayan communities in Bakun (Sagin et al., 2002). It is important to emphasise that the distinct differences in the distribution and rates of intestinal parasitism do not equate to direct correlation of the trend based on ethnicities. Rather, the causation is implicated by the varying degree of exposure and risks as indicated by different standards of living in different communities (Sagin et al., 2002). Nevertheless, different level of microscopists may underestimate or overstate the occurrence (Ryan et al., 2017), especially being aggravated by low infection intensity and similar morphology of some parasites (e.g. Ancylostoma duodenale, Necator americanus, Strongyloides stercoralis). Recommended screening includes repeated examination and sensitive diagnostic tools (Inês et al., 2011).

\section{Risk factors of intestinal parasitism}

Endemicity for intestinal parasites in developing countries is notably entrenched in areas with low socioeconomic status associated with low sanitation, malnutrition, close contact with the environment and overcrowding. Whereas, interconnections of these factors may be ambiguous and complex depending on areas and communities. Most of the populations involved are from the rural interior regions of Sarawak. High population density in an area directly contributes to the high risk of IPIs through environmental seeding and re-exposure especially in a condition that has close association with nature. This association is typically bound to low level of hygienic practices and sanitation (Sagin et al., 2002). Thus, this state of living exposes them to various transmission sources of infections, predominantly to those 
Tahar et al. (2021), Tropical Biomedicine 38(3): 377-386

Table 1. Summary of previous reports of human intestinal parasites from human samples in Sarawak

\begin{tabular}{|c|c|c|c|c|c|}
\hline Location & Population type & $\begin{array}{c}\text { Total } \\
\text { of } \\
\text { samples }\end{array}$ & Detected parasites & $\begin{array}{l}\text { Number } \\
\text { positive } \\
(\%)\end{array}$ & Source \\
\hline \multirow{10}{*}{$\begin{array}{l}\text { Pakan Town } \\
\text { (Sarikei Division) }\end{array}$} & Iban (3 longhouses) & 381 & Ascaris lumbricoides & $83(24.3)$ & Rajoo et al. (2017) \\
\hline & & & Hookworms & $75(22.0)$ & \\
\hline & & & Trichuris trichiura & $49(14.4)$ & \\
\hline & & & Entamoeba spp. & $22(6.5)$ & \\
\hline & & & Giardia lamblia & $12(3.5)$ & \\
\hline & & & Cryptosporidium spp. & $1(0.3)$ & \\
\hline & Iban (3 longhouses) & 236 & Strongyloides stercoralis & $5(2.1)$ & Ngui et al. (2016) \\
\hline & & & & $26(11.0)^{*}$ & \\
\hline & Iban (3 longhouses) & 212 & Toxoplasma gondii & $2(0.9)$ & Ngui et al. (2020) \\
\hline & & & & $106(50)^{*}$ & \\
\hline \multirow{20}{*}{$\begin{array}{l}\text { Bakun Valley } \\
\text { (Kapit Division) }\end{array}$} & Kayan (3 longhouses) & 304 & Trichuris trichiura & $116(38.16)$ & Sagin et al. (2002) \\
\hline & & & Ascaris lumbricoides & $18(5.9)$ & \\
\hline & & & Hookworms & $9(3.0)$ & \\
\hline & Kenyah (1 longhouse) & 7 & Trichuris trichiura & $2(28.6)$ & \\
\hline & & & Ascaris lumbricoides & $1(14.3)$ & \\
\hline & & & Hookworms & $2(28.6)$ & \\
\hline & Kajang (1 longhouse) & 42 & Trichuris trichiura & $8(19.0)$ & \\
\hline & & & Ascaris lumbricoides & $0(0.0)$ & \\
\hline & & & Hookworms & 5 (11.9) & \\
\hline & Ukit (1 longhouse) & 7 & Trichuris trichiura & $0(0.0)$ & \\
\hline & & & Ascaris lumbricoides & $0(0.0)$ & \\
\hline & & & Hookworms & $0(0.0)$ & \\
\hline & Penan (1 longhouse) & 24 & Trichuris trichiura & $4(16.7)$ & \\
\hline & & & Ascaris lumbricoides & $5(20.8)$ & \\
\hline & & & Hookworms & $0(0.0)$ & \\
\hline & Kayan (3 longhouses) & 183 & Schistosoma spp. & $15(8.2)^{*}$ & Sagin et al. (2001) \\
\hline & Kenyah (1 longhouse) & 44 & & $2(4.5)^{*}$ & \\
\hline & Lahanan (1 longhouse) & 43 & & $5(11.6)^{*}$ & \\
\hline & Ukit (1 longhouse) & 24 & & $0(0.0)^{*}$ & \\
\hline & Penan (1 longhouse) & 73 & & $3(4.1)^{*}$ & \\
\hline \multirow{3}{*}{$\begin{array}{l}\text { Serian Town } \\
\text { (Serian Division) }\end{array}$} & School children & - & Ascaris lumbricoides & - (18.0) & Singh \& Cox-Singh \\
\hline & & & Trichuris trichiura & $-(34.3)$ & $(2001)$ \\
\hline & & & Hookworms & $-(11.0)$ & Lee et al. (1999) \\
\hline \multirow{7}{*}{$\begin{array}{l}\text { Seratok } \\
\text { (Betong Division) }\end{array}$} & Iban & 142 & Hookworms & $67(47.2)$ & Neo et al. (1987) \\
\hline & & & Trichuris trichiura & $61(43.0)$ & \\
\hline & & & Enterobius vermicularis & $12(8.5)$ & \\
\hline & & & Ascaris lumbricoides & 7 (4.9) & \\
\hline & & & Giardia lamblia & $4(2.8)$ & \\
\hline & & & lodamoeba butschlii & $2(1.4)$ & \\
\hline & & & Chilomastix mesnili & $1(0.7)$ & \\
\hline Kapit Division & Chinese (case report) & 1 & Sarcocystis spp. & $1(100.0)$ & $\begin{array}{l}\text { Pathmanathan \& Kan } \\
\text { (1987) }\end{array}$ \\
\hline Kuching Division & Indonesian (case report) & 1 & Ascaris lumbricoides & $1(100.0)$ & Stephen \& Siow (2012) \\
\hline \multirow{5}{*}{$\begin{array}{l}\text { Baram } \\
\text { (Miri Division) }\end{array}$} & Penan (1 longhouse) & 120 & Ascaris lumbricoides & $16(13.3)$ & Kan et al. (1987) \\
\hline & & & Hookworms & $16(13.3)$ & \\
\hline & & & Trichuris trichiura & $13(10.8)$ & \\
\hline & & & Enterobius vermicularis & $1(0.8)$ & \\
\hline & & & Entamoeba spp. & $3(2.5)$ & \\
\hline \multirow{3}{*}{$\begin{array}{l}\text { Two hospitals } \\
\text { in Lundu and } \\
\text { Serian }\end{array}$} & Hospital patients & 94 & Ascaris lumbricoides & $6(6.4)$ & Othman et al. (2015) \\
\hline & & & Strongyloides stercoralis & $29(30.9)$ & \\
\hline & & & Hookworms & $28(29.8)$ & \\
\hline \multirow{3}{*}{$\begin{array}{l}\text { Two districts } \\
\text { hospitals }\end{array}$} & Hospital patients & 77 & Ascaris lumbricoides & $6(7.8)$ & Basuni et al. (2011) \\
\hline & & & Strongyloides stercoralis & $30(39.0)$ & \\
\hline & & & Hookworms & 31 (40.1) & \\
\hline
\end{tabular}

Note: "-" denotes the information is not available. “*” denotes the positive finding was based on seropositivity test. 
circulating in contaminated environments (i.e. water sources, soil and animals). In most remote areas with poor accessibility, the river plays an important route in transportation. Among the Iban communities in Pakan as reported by Rajoo et al. (2017), the risk factors which are toilet non-existence, close contact with animals, taking bath once a day and changing clothes once a day correlated with IPIs. Unsanitary defecation is due to the lack of household toilets that is almost non-existent, except for the existence of a single pit latrine shared among various households. Therefore, indiscriminate defecation is mostly practised and remains as the sole available solution that sequentially aggravates transmission of intestinal parasites, especially when the contamination reaches the river water system.

\section{Burdens of intestinal parasitism}

There are many studies globally describing the effects of IPIs on growth and socio-development. However, this part of the review only focuses on the situation implicated among the Sarawak populations. Generally, symptoms of IPIs may vary from asymptomatic to chronic infections. In the perspective of pathophysiology, some sequelae can be observed in infected individuals that can affect growth and socio-development, particularly caused by soil-transmitted helminths (STHs). As in a study by Rajoo et al. (2017) among Iban communities in Sarikei, there were associations of STHs (A. lumbricoides, T. trichuria and hookworm) with anaemia in a trend of decreasing haemoglobin value when there is an increase in infection intensity. Moreover, a thorough analysis to elucidate the pattern of infection demonstrated that polyparasitism by $T$. trichiura and hookworm significantly correlated with anaemia. Nevertheless, stunting and underweight were also recorded in IPIs-infected individuals. The high prevalence of intestinal parasites among the rural communities may carry a health burden to non-endemic areas through the dynamic movement of the infected individuals such as migration by forest workers. Deposition of parasite eggs and (oo)cysts into the new environment can happen particularly in areas where personal hygiene, sanitation and safe water supply are minimal (Pearson, 2002), hence leading to initiation of the infection circle among the new communities.

\section{Waterborne transmission}

Occurrence of parasites in drinking water supply

At present, there are four studies on the prevalence of waterborne parasites in Sarawak is available, which involved different water types such as from water treatment plants, such as in Batu Kitang, Matang, Bau and Siniawan (Richard et al., 2016; Lo et al., 2018; Tahar et al., 2019), rivers in Batu Kitang and Bau (Bilung et al., 2017), a gravity-feed system in Bau (Tahar et al., 2019) and a lake in Samarahan and Ranchan (Bilung et al., 2017) involving Kuching and Serian Division as displayed in Figure 1 \& Table 2. In retrospect of cryptosporidiosis and giardiasis outbreaks globally, Cryptosporidium and Giardia have been classified as a major concern owing to high transmission potential in water systems (Baldursson \& Karanis, 2011). In Sarawak, these parasites have been found in a concentration ranging from $0.0-2.7$ oocysts/L for Cryptosporidium (22.5\%, 48/206) and 0.0 - 1.2 cysts/L for Giardia (26.0\%, 43/165). Other waterborne intestinal parasites also have been encountered but with lower occurrence, which are Schistosoma spp. (1.4\%, 1/69, range: $0-0.1 \mathrm{ova} / \mathrm{L})$, Cylospora cayetanensis ( $8.3 \%, 4 / 48$, range: $0-0.6$ oocysts/L), nematode larvae $(5.8 \%, 4 / 69$, range: $0-0.4$ larvae/ $\mathrm{L})$, Ascaris lumbricoides (2.9\%, 2/24, range: $0-0.2 \mathrm{ova} / \mathrm{L})$, hookworms (2.9\%, 2/24, range: $0-0.1 \mathrm{ova} / \mathrm{L})$ and Enterobius vermicularis $(1.4 \%, 1 / 69,0-0.1$ ova/L).

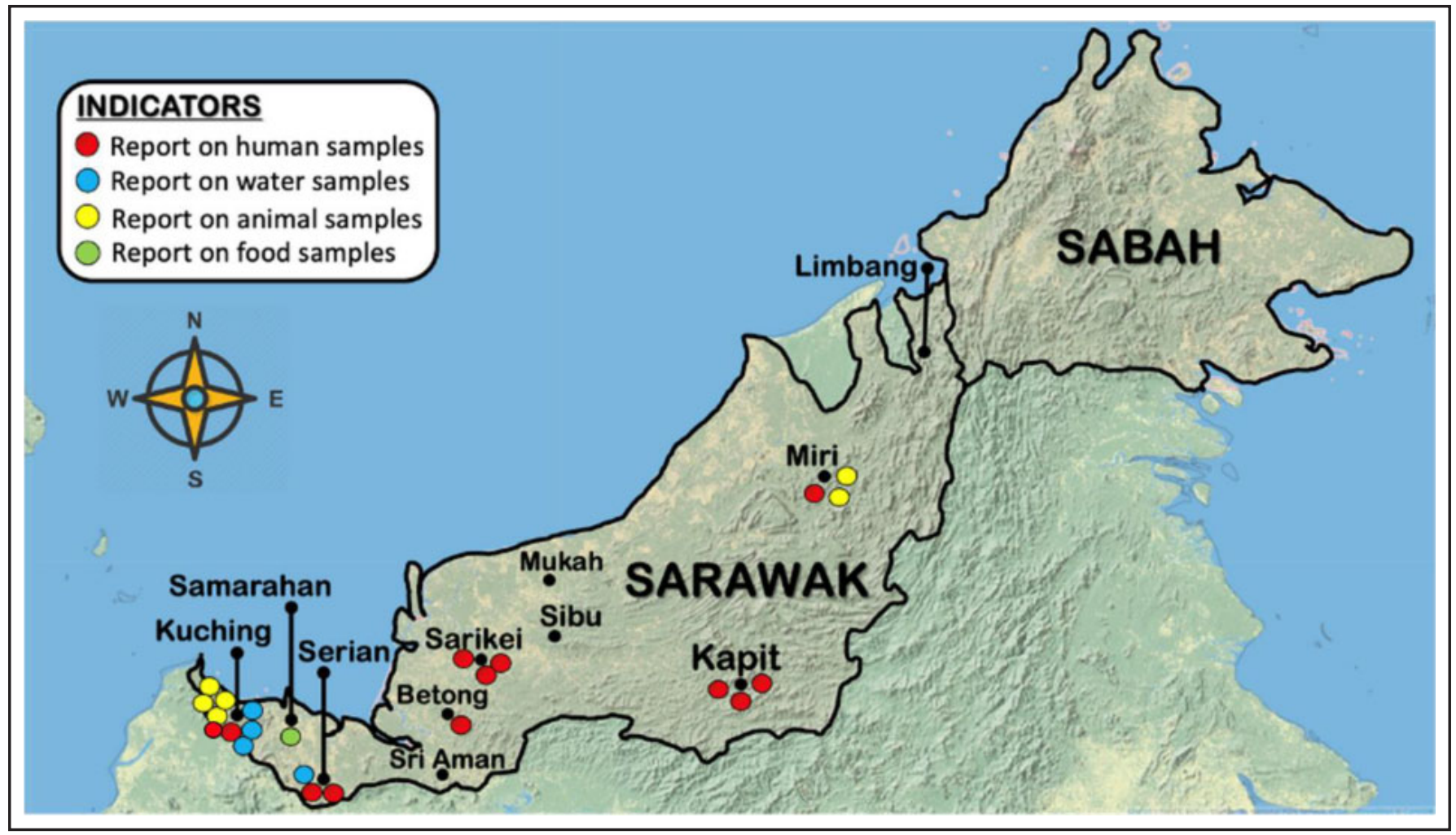

Figure 1. Previous reports on intestinal parasites from different samples (humans, water, animals and food) across Sarawak State. Each indicator only represents the division of where the data were reported and not their exact sublocation (i.e. district, village, etc.). However, studies with none sample localities mentioned are not plotted on the map. 


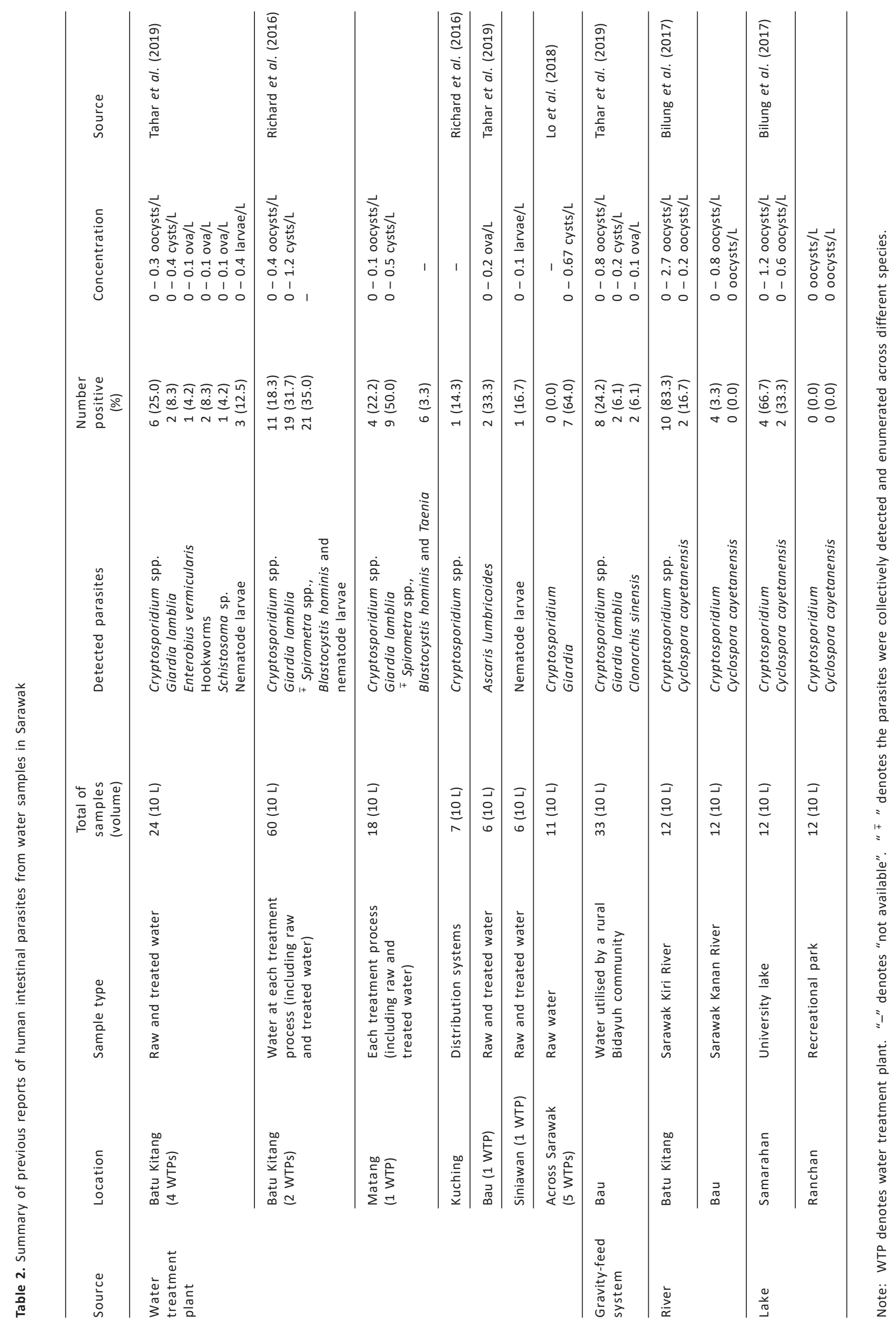


Risks of waterborne infections have become more apparent after a study by Lo et al. (2018) highlighted that five water treatment plants (WTPs) operated in Southern, Central and Northern Sarawak have inadequate removal efficiency for Cryptosporidium and Giardia. Failure of the WTPs to score log removal credits was mainly due to the lack of real-time turbidity and chlorine-based disinfectants were used alone throughout the treatment processes. In which, Cryptosporidium is resistant to most disinfectants utilised in conventional water treatment systems, a multi-barrier approach comprising different disinfections and filtrations is suggested (Betancourt \& Rose, 2008) including within households. Water contamination is often overlooked due to the current lack of routine examination for protozoa and helminths in water treatment.

Water can be rendered safe from parasites, particularly Cryptosporidium, if being treated using reverse osmosis, rolling boil at least for 1 minute or a certified filtration system (CDC, 2015). However, the practice of proper water treatments at the point-of-entry (POE) and point-of-use (POU) is far from proliferating especially among the rural communities. In some rural areas, centrally supplied water from rural water treatment plants is not entirely distributed to the rest of the populations because of the extra cost of piping network installation and the requirement of appropriate monitoring of the pipes. In a local scenario of Tringgus area in Bau, the rural Bidayuh community are solely dependent on a gravityfeed system without additional treatments except boiling despite being in the territory of Bau WTP which produces water for rural areas (Tahar et al., 2019).

\section{Zoonotic transmission}

Generally, intestinal parasites exhibit host specificity for infection. However, some parasites are zoonotic that can pass the diseases from animals to humans. Broadly, zoonotic transmission can be acquired from direct contacts (i.e. companions, livestock and wild animals) or consumption of undercooked meat of the infected animals. As of now, there have been seven studies in Sarawak reporting the occurrences of zoonotic intestinal parasites in animals, namely in dogs, pigs, non-human primates and rats involving Kuching and Serian Division as displayed in Figure 1 and Table 3.

Based on the available data from previous studies in 1987 - 2000, a number of dogs sampled in districts of Kuching, Baram and Bario were found to be hosting hookworms (58.5\%, $38 / 65)$ and Toxocara sp. that can cause human infections (12.5\%, 4/32) (Kan et al., 1987; Choo et al., 2000). However, it is only since these years that such data have been produced. In local settings, dogs are close companions especially for rural communities for hunting and entering the jungle. Stray dogs are highly exposed to various infectious diseases and can be a successful host for parasite transmission. Two studies showed stray dogs carry hookworms (Choo et al., 2000) and Toxoplasma gondii (Watanabe et al., 2020) in Kuching. An average of 125 adult hookworms were enumerated from dissected stray dogs (Choo et al., 2000), while T. gondii were detected in 9 of 37 dogs (24.3\%) based on serological test. The onset of transmission takes place when defecated ova or oocysts in stool are voided in the soil and thrive. The risk is compounded by low hygienic practices, such as walking outside barefooted. Infection also can occur from ingestion of infective stage of the parasites (Landmann \& Prociv, 2003).

There are two studies of animals in captivity in Sarawak. A study by Tan et al. (2014) found that captivated pigs from a farm in Bau are infected with Balantidium coli $(59.1 \%, 13 / 22)$, Entamoeba sp. $(9.1 \%, 2 / 22)$ and $T$. suis $(4.5 \%, 1 / 22)$. Pigs had accounted for the largest livestock population in Sarawak (89.3\% - 96.0\%) from 2012 - 2018 among other animals such as buffaloes, cattle, goats and sheep (DVS, 2019). Apart from passing the parasitic diseases through the foodborne route, a focal contribution to human transmission may be facilitated by direct contacts or faecal-oral routes to the farm workers with the animals. Thus, such prevalence

Table 3. Summary of previous reports of human intestinal parasites from animal samples in Sarawak

\begin{tabular}{|c|c|c|c|c|c|c|}
\hline Source & Location & Sample type & $\begin{array}{l}\text { Total of } \\
\text { samples }\end{array}$ & Detected parasites & $\begin{array}{l}\text { Number } \\
\text { positive (\%) }\end{array}$ & Source \\
\hline \multirow[t]{4}{*}{ Dog } & Kuching & Stray dogs & 8 & Hookworms & $8(100.0)$ & Choo et al. (2000) \\
\hline & Baram & $\begin{array}{l}\text { Companions of } \\
\text { indigenous communities }\end{array}$ & 32 & $\begin{array}{l}\text { Hookworms } \\
\text { Toxocara sp. }\end{array}$ & $\begin{array}{l}6(25.0) \\
4(16.7)\end{array}$ & Kan et al. (1987) \\
\hline & Bario & - & 25 & Hookworms & $24(96.0)$ & $\begin{array}{l}\text { Prociv (1995) [unpublished] } \\
\text { as in Kan et al. (1987) }\end{array}$ \\
\hline & - & Stray dogs & 37 & Toxoplasma gondii & $9(24.3)^{*}$ & Watanabe et al. (2020) \\
\hline Pig & Bau & Farmed pigs & 22 & $\begin{array}{l}\text { Balantidium coli } \\
\text { Entamoeba sp. } \\
\text { Trichuris suis }\end{array}$ & $\begin{aligned} 13 & (59.1) \\
2 & (9.1) \\
1 & (4.5)\end{aligned}$ & Tan et al. (2014) \\
\hline $\begin{array}{l}\text { Non-human } \\
\text { primates }\end{array}$ & Matang & $\begin{array}{l}\text { Captivated in a } \\
\text { wildlife centre }\end{array}$ & 60 & $\begin{array}{l}\text { Ascaris sp. } \\
\text { Capillaria sp. } \\
\text { Hookworms } \\
\text { Oesophagostomum sp. } \\
\text { Strongyloides sp. } \\
\text { Trichuris sp. }\end{array}$ & $\begin{array}{c}(23.3) \\
(1.6) \\
(1.6) \\
(15.0) \\
(40.0) \\
(3.3-13.3)\end{array}$ & Teo et al. (2019) \\
\hline \multirow[t]{3}{*}{ Rat } & Kuching & Rice fields & 22 & $\begin{array}{l}\text { Angiostrongylus } \\
\text { cantonensis }\end{array}$ & $2(9.1)$ & $\operatorname{Lim}(1967)$ \\
\hline & & Scrub vegetation & 100 & & $11(50.0)$ & \\
\hline & & Secondary forest & 40 & & $0(0.0)$ & \\
\hline
\end{tabular}

Note: “-" denotes "not available". “*” denotes the positive finding was based on seropositivity test. 
Table 4. Summary of previous reports of human intestinal parasites from food samples in Sarawak

\begin{tabular}{|c|c|c|c|c|c|c|c|}
\hline Source & Location & Sample type & $\begin{array}{c}\text { Total } \\
\text { of } \\
\text { samples }\end{array}$ & Detected parasites & $\begin{array}{l}\text { Number } \\
\text { positive } \\
(\%)\end{array}$ & Concentration & Source \\
\hline Vegetables & Samarahan & $\begin{array}{l}\text { Retailed vegetables } \\
\text { (comprising root } \\
\text { and leafy-types } \\
\text { of vegetables) }\end{array}$ & 108 & $\begin{array}{l}\text { Cryptosporidium spp. } \\
\text { Giardia lamblia } \\
\text { Hookworms } \\
\text { Nematode larvae }\end{array}$ & 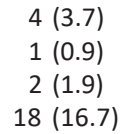 & $\begin{array}{l}0-0.03 \text { oocysts/g } \\
0-0.01 \text { cysts/g } \\
0-0.02 \text { ova/g } \\
0-0.71 \text { larvae/g }\end{array}$ & $\begin{array}{l}\text { Tahar et al. } \\
\text { (2021) }\end{array}$ \\
\hline Exotic meats & - & $\begin{array}{l}\text { Civet cat meat } \\
\text { Monkey meat } \\
\text { Squirrel meat }\end{array}$ & $\begin{array}{l}2 \\
2 \\
2\end{array}$ & $\begin{array}{l}\text { Sarcocystis hominis } \\
\text { Toxoplasma sp. } \\
\text { Toxoplasma sp. }\end{array}$ & $\begin{array}{l}- \\
- \\
-\end{array}$ & $\begin{array}{l}- \\
- \\
-\end{array}$ & $\begin{array}{l}\text { Fazly et al. } \\
\text { (2013) }\end{array}$ \\
\hline
\end{tabular}

Note: “" denotes "not available".

requires extensive surveillance before any conditions causing resultant overflow of IPIs to consumers if high prevalence is not initially controlled. The second study by Teo et al. (2019) found that captivated non-human primates were positive against Ascaris sp. (23.3\%), Capillaria sp. (1.6\%), hookworms (1.6\%), Oesophagostomum sp. (15\%), Strongyloides sp. (40\%), and Trichuris sp. (3.3-13.2\%) (Teo et al., 2019) from a Matang Wildlife Centre in Kuching. Despite being in captivity, the infected animals may still represent a source of infection to the workers and other animals having close contact. This study represents a pioneer for samples related to tourism, and more studies are required to understand the extent for human transmission potential using molecular approaches.

In another study, scavenging rats $(8.03 \%, 13 / 162)$ were detected with Angyostrongylus cantonensis, a rat lungworm sampled from paddy fields, scrub vegetation and secondary forests (Lim, 1967). Nevertheless, the authors also emphasised that important hosts (i.e. snail species of Achatina julica, Microparmarion malayanus and Macrochlamys resplendens) were common in the scrub areas but not examined, thus knowledge of the host distribution still remains as a gap. The occurrence of this parasitic nematode in rats (i.e. definitive host) therefore support possible lifecycle in intermediate hosts, such as snails, slugs, freshwater shrimps and frogs. Humans can act as an accidental host through ingestion of these undercooked intermediate hosts. Infection morbidity in humans is manifested with eosinophilic meningitis (Barratt et al., 2016). It is worth noting that there is no recent finding on the occurrence of this parasite in Sarawak. Therefore, this lack of focus may be explained by no clinical cases which have been reported thus far, leading to being deemed as an insignificant disease. Unlike in other countries (i.e. Thailand, China, Australia) where such cases are frequently reported, the parasitic nematode has not been given due attention in Malaysia (Wang et al., 2012; Berkhout et al., 2019).

\section{Foodborne transmission}

Thus far, studies on foodborne intestinal parasites in Sarawak are still limited to only two studies which reported contamination on vegetables and exotic meats as shown in Table 4. A study on fresh retailed vegetables by Tahar et al. (2021) reported that Cryptosporidium (3.7\%, 4/108, range: 0 0.03 oocysts/g), Giardia (0.9\%, 1/108, range: $0-0.01$ cysts/g), hookworm (1.9\%, 2/108, range: $0-0.02$ ova/g), nematode larvae $(16.7 \%, 18 / 108$, range: $0-0.71$ larvae/g) were found in fresh retailed vegetables in Samarahan Division (Figure 1). Cryptosporidium, Giardia, Toxoplasma, and Sarcocystis are among those which have already been ranked by Food and Agriculture Organization of the United Nations (FAO) in the top global ranking of foodborne parasites (FAO, 2014) and top foodborne parasites linked to Disability Adjusted Life Years (DALY) in 2010 (Torgerson et al., 2015). Epidemiological circumstances of these foodborne parasites are initiated when contaminated foods are not hygienically prepared and cooked. Another study found the occurrence of Sarcocystis and Toxoplasma in exotic meats of civet cats, monkeys, and squirrels collected in Sarawak (Fazly et al., 2013). However, information such as the prevalence and concentration of the parasites as well as name of the division involved are not available in the article, thus the details are not mentioned in Figure 1 and Table 4. The association of exotic wildlife meats has been well explained and linked to emerging zoonotic diseases. In a review on traded exotic meats in Malaysia, a total of 16 zoonotic parasites from traded wildlife may cause human infections, with Sarcocystis, Toxoplasma, and Trichinella species being addressed as three foodborne parasites mostly found in wildlife (Cantlay et al., 2017). In the rural communities in Sarawak, culturally-routed dietary habit of eating exotic meats such as deer, wild boars, snakes, and lizards is prevalent, and this practice is bound to folklore medicine and sustenance. Wild meats are mainly consumed to complement the scarce poultry and meat sources in rural areas of Sarawak (Yi \& Mohd-Azlan, 2018), the reasoning behind the prevalent practice of eating wild meats in rural areas. The locals are also allowed to consume or possess not more than five kilograms of wild meats according to the laws (SWLPO, 1998). Thus far, no apparent cases of IPIs acquired from eating exotic meats have been recorded clinically. The true prevalence somehow could have been obscured by asymptomatic and subclinical cases, unless being incidentally discovered during a course of medical procedures. For example, there was a rare case in Keningau, Sabah (a part of Borneo) where Armillifer moniliformis were found in an aborigine after autopsy for pancreatic malignancy. The patient had history eating undercooked python which that was singled out as a source of infection (Latif et al., 2013).

\section{CONCLUSIONS}

This review collates and provides a recent summary of all accessible published data on human intestinal parasites in humans and environments (i.e. water, animals and food samples) in Sarawak, East Malaysia. It is indisputable, based on the tables above, that data deficiency is evident thus underestimating the true prevalence of intestinal parasites in the state. Despite intestinal parasitic infections having a global importance, they do not receive continuous vigilance in Sarawak because of being overshadowed by other more 
important diseases such as malaria and rabies that are currently endemic in the state. Some limitations from previous studies are addressed; first, standard and sensitive tools were not adopted in some studies, which translate equivocal finding. Second, lack of detailed descriptions (i.e. exact localities, prevalence number) were often encountered in some studies, by which such data transparency would provide local elementary understanding. Third, clinical IPIs at healthcare settings were not continuously reported. Given these factors intertwined, a more coherent research design should be mapped out, incorporating other high-risk areas and people with general symptoms of IPIs. The effects of controlling IPIs (i.e. mass deworming) locally have not been assessed to contemplate the relationships with poverty, marginalisation and adaptive immunity from other diseases. As much finding from this review highlighted the rural communities, it still does not exclude the risk of IPIs among urban communities in Sarawak despite the patterns and vehicles of transmission may be varied in both rural and urban areas. This review urges for a change in attitude and notion towards parasitic infections. Besides, collaborative interdisciplinary strategies to elucidate epidemiology should be integrated into future studies to improve the livelihood of rural communities and control high emergence of parasitic infections in Sarawak.

\section{List of abbreviations}

DALY: Disability Adjusted Life Years; FAO: Food and Agriculture Organization of the United Nations; HFMD: Hand, foot, and mouth disease; IPIs: intestinal parasitic infections; JBALB: Sarawak Rural Water Supply Department; JE: Japanese encephalitis; KWB: Kuching Water Board; LAKU: Northern Region Water Board; POE: point-of-entry; POU: point-of-use; STHs: soil-transmitted helminths; WTP: water treatment plant.

\section{ACKNOWLEDGEMENTS}

The authors would like to acknowledge all contribution made by authors of previous studies in Sarawak. The data produced, even in preliminary studies, are beneficial in providing elemental information in the local settings of Sarawak.

\section{Competing interests}

The authors declare that they have no competing interests.

\section{REFERENCES}

Baldursson, S. \& Karanis, P. (2011). Waterborne transmission of protozoan parasites: review of worldwide outbreaksan update 2004-2010. Water Research 45: 6603-6614. https://doi.org/10.1016/j.watres.2011.10.013

Barratt, J., Chan, D., Sandaradura, I., Malik, R., Spielman, D., Lee, R., Marriott, D., Harkness, J., Ellis, J. \& Stark, D. (2016). Angiostrongylus cantonensis: a review of its distribution, molecular biology and clinical significance as a human pathogen. Parasitology 143: 1087-1118. https://doi.org/ 10.1017/S0031182016000652

Basuni, M., Muhi, J., Othman, N., Verweij, J.J., Ahmad, M., Miswan, N., Rahumatullah, A., Abdul Aziz, F., Zainudin, N.S. \& Noordin, R. (2011). A pentaplex real-time polymerase chain reaction assay for detection of four species of soil-transmitted helminths. The American Journal of Tropical Medicine and Hygiene 84: 338-343. https://doi.org/ 10.4269/ajtmh.2011.10-0499
Berkhout, A., Prociv, P., Anthony, H., Anthony, L.T. \& Clare, N. (2019). Two cases of neuroangiostrongyliasis: A rare disease because rarely considered or rarely diagnosed? Journal of Paediatrics and Child Health 55: 1463-1469. https://doi.org/10.1111/jpc.14461

Betancourt, W.Q. \& Rose, J.B. (2004). Drinking water treatment processes for removal of Cryptosporidium and Giardia. Veterinary Parasitology 126: 219-234. https://doi.org/10.1016/ j.vetpar.2004.09.002

Bilung, L.M., Tahar, A.S., Yunos, N.E., Apun, K., Lim, Y.A.L., Nillian, E. \& Hashim, H.F. (2017). Detection of Cryptosporidium and Cyclospora oocysts from environmental water for drinking and recreational activities in Sarawak, Malaysia. BioMed Research International 2017: 4636420. https://doi.org/ $10.1155 / 2017 / 4636420$

Cantlay, J.C., Ingram, D.J. \& Meredith, A.L. (2017). A review of zoonotic infection risks associated with the wild meat trade in Malaysia. EcoHealth 14: 361-388. https://doi.org/ 10.1007/s10393-017-1229-x

Centers for Disease Control and Prevention, CDC (2015). A Guide to Water Filters. Retrieved from https://www.cdc. gov/parasites/crypto/gen_info/filters.html

Cheong, F.W., Lau, Y.L., Fong, M.Y. \& Mahmud, R. (2013). Evaluation of recombinant Plasmodium knowlesi merozoite surface protein-133 for detection of human malaria. The American Journal of Tropical Medicine and Hygiene 88: 835840. https://doi.org/10.4269/ajtmh.12-0250

Choo, J., Pang, E. \& Prociv, P. (2000). Hookworms in dogs of Kuching, Sarawak (North Borneo). Transactions of the Royal Society of Tropical Medicine and Hygiene 94: 21-22. https:// doi.org/10.1016/S0035-9203(00)90425-5

Department of Statistics Malaysia, DOSM (2021). Current Population Estimates Malaysia, 2021. Retrieved from https://newss.statistics.gov.my/newss-portalx/ep/ epFreeDownloadContentSearch.seam?cid $=1320850$

Department of Veterinary Services Malaysia, DVS (2019). Sarawak: Livestock Population, 2012-2018. Retrieved from http://www.dvs.gov.my/dvs/resources/user_1/2019/BP/ Perangkaan\%20Ternakan/13._Sarawak_Perangkaan_ ternakan_M_Surat_61-63_.pdf

Fazly, Z.A., Nurulaini, R., Shafarin, M.S., Fariza, N.J., Zawida, Z., Muhamad, H.Y., Adnan, M., Premaalatha, B., Erwanas, A.I., Zaini, C.M. et al. (2013). Zoonotic parasites from exotic meat in Malaysia. Tropical Biomedicine 30: 535-542.

Food and Agriculture Organization of the United Nations, FAO (2014). Multicriteria-Based Ranking for Risk Management of Food-Borne Parasites. Microbiological Risk Assessment Series (MRA) 23. Retrieved from http://www. fao.org/publications/card/en/c/ee07c6ae-b86c-4d5f915c-94c93ded7d9e/

Hartgers, F.C. \& Yazdanbakhsh, M. (2006). Co infection of helminths and malaria: modulation of the immune responses to malaria. Parasite Immunology 28(10): 497-506. https://doi.org/10.1111/j.1365-3024.2006.00901.x

Impoinvil, D.E., Ooi, M.H., Diggle, P.J., Caminade, C., Cardosa, M.J., Morse, A.P., Baylis, M. \& Solomon, T. (2013). The effect of vaccination coverage and climate on Japanese encephalitis in Sarawak, Malaysia. PLoS Neglected Tropical Diseases 7: e2334. https://doi.org/10.1371/journal.pntd. 0002334

Inês, E.D.J., Souza, J.N., Santos, R.C., Souza, E.S., Santos, F.L., Silva, M.L.S., Silva, M.P., Teixera, M.C.A. \& Soares, N.M. (2011). Efficacy of parasitological methods for the diagnosis of Strongyloides stercoralis and hookworm in faecal specimens. Acta Tropica 120: 206-210. https://doi. org/10.1016/j.actatropica.2011.08.010 
Kan, S.P., Yap, S.B. \& Yap, P.L. (1987). Intestinal parasitism among Penan children of the Upper Baram, Sarawak. Asia Pacific Journal of Public Health 1: 38-41. https://doi.org/10.1177\%2 F101053958700100110

Landmann, J.K. \& Prociv, P. (2003). Experimental human infection with the dog hookworm, Ancylostoma caninum. Medical Journal of Australia 178: 69-71. https://doi.org/ 10.5694/j.1326-5377.2003.tb05066.x

Latif, B., Omar, E., Heo, C.C., Othman, N. \& Tappe, D. (2011). Human pentastomiasis caused by Armillifer moniliformis in Malaysian Borneo. The American Journal of Tropical Medicine and Hygiene 85: 878-881. https://doi.org/10.4269/ ajtmh.2011.11-0404

Lee, D.L., Lee, S., Chang, M.S., Paon, A.J. \& Katip, J.T. (1999). Intestinal helminth infections amongst school children in the Serian District of Sarawak. The Medical Journal of Malaysia 54: 96-101.

Lim, B.L. (1967). Occurrence of Angiostrongylus cantonensis in rats around Kuching, Sarawak. Annals of Tropical Medicine \& Parasitology 61: 429-431. https://doi.org/10.1080/ 00034983.1967.11686510

Lo, N.T., Sarker, M.A.B., Lim, Y.A.L., Harun-Or-Rashid, M. \& Sakamoto, J. (2018). Inadequate water treatment quality as assessed by protozoa removal in Sarawak, Malaysia. Nagoya Journal of Medical Science 80: 165. https://doi.org/ 10.18999/nagjms.80.2.165

Mohan, A., Podin, Y., Tai, N., Chieng, C.H., Rigas, V., Machunter, B., Mayo, M., Wong, D., Chien, S.L., Tan, L.S. et al. (2017). Pediatric melioidosis in Sarawak, Malaysia: Epidemiological, clinical and microbiological characteristics. PLOS Neglected Tropical Diseases 11: e0005650. https://doi.org/ 10.1371/journal.pntd.0005650

Muthu, V. (2018). Rabies Malaysia. Retrieved from https:// rabiesalliance.org/resource/lessons-learned-malaysia

National Water Services Commission, SPAN (2018a). Treatment Plant Design Capacity and Production 2015-2016. Retrieved from http://www.span.gov.my/article/view/ treatment-plant-design-capacity-and-production-20152016

National Water Services Commission, SPAN (2018b). Water Consumption 2015-2016. Retrieved from http://www.span. gov.my/article/view/water-consumption-2015-2016

Neo, C.B., Cheah, Y.K., Chin, P.W., Tan, T.V., Wong, N.C., Yap, L.M. \& Kan, S.P. (1987). Prevalence and distribution of intestinal and blood parasites among Ibans in the Nanga Atoi in the Second Division in Sarawak. Medical Journal of Malaysia 42: 294-298.

Ngui, R., Hassan, N.A., Chang, L.Y., Teh, S.J.C., Chua, K.H., Kee, B.P., Hoe, S.Z. \& Lim, Y.A.L. (2020). Toxoplasma gondii infection among selected indigenous community in Sarawak, East Malaysia. Tropical Biomedicine 37: 155-164.

Ngui, R., Halim, N.A.A., Rajoo, Y., Lim, Y.A.L., Ambu, S., Rajoo, K., Chang, T.S., Woon, L.C. \& Mahmud, R. (2016). Epidemiological characteristics of strongyloidiasis in inhabitants of indigenous communities in Borneo island, Malaysia. The Korean Journal of Parasitology 54: 673. https://doi.org/ 10.3347/kjp.2016.54.5.673

Othman, N., Basuni, M., Muhi, J., Miswan, N. \& Noordin, R. (2015). Soil-transmitted helminth infections among malaria patients determined by microscopy and real-time PCR methods at two district hospitals in Sarawak, Malaysia. Tropical Biomedicine 32: 710-716.

Pathmanathan, R. \& Kan, S.P. (1987). Two cases of human sarcocystosis in East Malaysia. Medical Journal of Malaysia 42: $212-214$.
Patrick, G.B., Nishibuchi, M., Tunung, R. \& Radu, S. (2012). Molecular characterization of clinical isolate of Vibrio cholerae isolated from outbreaks cases in Malaysia. International Food Research Journal 19: 1267-1274.

Pearson, R.D. (2002). An update on the geohelminths: Ascaris lumbricoides, hookworms, Trichuris trichiura, and Strongyloides stercoralis. Current Infectious Disease Reports 4: 59-64. https:/ /doi.org/10.1007/s11908-002-0068-1

Rajoo, Y., Ambu, S., Lim, Y.A.L., Rajoo, K., Tey, S.C., Lu, C.W. \& Ngui, R. (2017). Neglected intestinal parasites, malnutrition and associated key factors: A population based cross-sectional study among indigenous communities in Sarawak, Malaysia. PLoS One 12: e0170174. https://doi.org/10.1371/journal.pone.0170174

Richard, R.L., Ithoi, I., Abd Majid, M.A., Wan Sulaiman, W.Y., Tan, T.C., Nissapatorn, V. \& Lim, Y.A.L. (2016). Monitoring of waterborne parasites in two drinking water treatment plants: a study in Sarawak, Malaysia. International Journal of Environmental Research and Public Health 13: 641. https:// doi.org/10.3390/ijerph13070641

Ryan, U., Paparini, A. \& Oskam, C. (2017). New technologies for detection of enteric parasites. Trends in Parasitology 33: 532-546. https://doi.org/10.1016/j.pt.2017.03.005

Sagin, D.D., Ismail, G., Fui, J.N. \& Jok, J.J. (2001). Schistosomiasis malayensis-like infection among the Penan and other interior tribes (Orang Ulu) in upper Rejang River Basin Sarawak Malaysia. The Southeast Asian Journal of Tropical Medicine and Public Health 32: 27-32.

Sagin, D.D., Mohamed, M., Ismail, G., Jok, J.J., Lim, L.H. \& Pui, J.N. (2002). Intestinal parasitic infection among five interior communities at upper Rejang River, Sarawak, Malaysia. Southeast Asian Journal of Tropical Medicine and Public Health 33: 18-22.

Sarawak Wild Life Protection Ordinance, SWLO (1998). Laws of Sarawak, Forest Department Sarawak.

Sercombe, P.G. (2020). Identity and Eastern Penan in Borneo. Journal of Modern Languages 30: 77-100. https://doi.org/ 10.22452/jml.vol30no1.2

Sham, N.M., Krishnarajah, I., Ibrahim, N.A. \& Lye, M.S. (2014). Temporal and spatial mapping of hand, foot and mouth disease in Sarawak, Malaysia. Geospatial Health 8: 503507. https://doi.org/10.4081/gh.2014.39

Singh, B. \& Cox-Singh, J. (2001). Parasites that cause problems in Malaysia: soil-transmitted helminths and malaria parasites. TRENDS in Parasitology 17: 597-600. https:// doi.org/10.1016/S1471-4922(01)02148-1

Stephen, D.D. \& Siow, S.L. (2012). Acute lower gastrointestinal haemorrhage secondary to small bowel ascariasis. The Malaysian Journal of Medical Sciences 19: 92-95.

Tahar, A.S. (2019). Dissertation: Distribution of waterborne parasites in raw and treated water from the selected water sources in Kuching Division. Universiti Malaysia Sarawak.

Tahar, A.S., Bilung, L.M., Goh, C.S.K., Nillian, E., Lim, Y.A.L., Richard, R.L., Hashim, H.F. \& Apun, K. (2021). Contamination of Intestinal Parasites in Vegetables from Kuching. International Journal of Current Research and Review 13: 31. http://dx.doi.org/10.31782/IJCRR.2021.SP135

Tan, T.K., Low, V.L., Lee, S.C., Chandrawathani, P., Premaalatha, B. \& Lim, Y.A.L. (2014). Gastro-intestinal parasitism among two swine populations in Malaysia: highlighting the zoonotic transmissible protozoan Balantidium coli infections. Malaysian Journal of Veterinary Research 5: 6368. 
Teo, S.Z., Tuen, A.A., Madinah, A., Aban, S. \& Chong, Y.L. (2019). Occurrence of gastrointestinal nematodes in captive nonhuman primates at Matang Wildlife Centre, Sarawak. Tropical Biomedicine 36: 594-603.

Thayaparan, S., Robertson, I.A.N., Amraan, F., Su'ut, L. \& Abdullah, M.T. (2013). Serological prevalence of leptospiral infection in wildlife in Sarawak, Malaysia. Borneo Journal of Resource of Science and Technology 2: 79-82.

Ting, S.H. \& Ling, T.Y. (2013). Language use and sustainability status of indigenous languages in Sarawak, Malaysia. Journal of Multilingual and Multicultural Development 34: 7793. https://doi.org/10.1080/01434632.2012.706301

Torgerson, P.R., Devleesschauwer, B., Praet, N., Speybroeck, N., Willingham, A.L., Kasuga, F., Rokni, M.B., Zhou, X.N., Fèvre, E.M., Sripa, B. et al. (2015). World Health Organization estimates of the global and regional disease burden of 11 foodborne parasitic diseases, 2010: A data synthesis. PLoS Medicine 12(12): e1001920. https://doi.org/ 10.1371/journal.pmed.1001920
Wang, Q.P., Wu, Z.D., Wei, J., Owen, R.L. \& Lun, Z.R. (2012). Human Angiostrongylus cantonensis: an update. European Journal of Clinical Microbiology \& Infectious Diseases 31: 389395. https://doi.org/10.1007/s10096-011-1328-5

Watanabe, M., Sadiq, M.B., Mulop, N.I.A., Mohammed, K., Rani, P.A.M., Fong, L.S., Aziz, N. A., Kamaludeen, J., Ramanoon, S.Z., Mansor, R. et al. (2020). Prevalence of Toxoplasma gondii antibodies in stray dogs from various locations in West and East Malaysia. The Korean Journal of Parasitology 58: 487. https://dx.doi.org/10.3347\%2Fkjp.2020.58.5.487

Yi, M.C.K. \& Mohd-Azlan, J. (2018). Preliminary Analysis on the Hunting Activities in Selected Areas in Interior Sarawak. Malaysian Applied Biology Journal 47: 37-43. 